\title{
Inter-regional correlation of palaeoclimatic records for the Last Glacial-Interglacial Transition: a protocol for improved precision recommended by the INTIMATE project group
}

\author{
J. John Lowe ${ }^{\mathrm{a}, *}$, Wim Z. Hoek ${ }^{\mathrm{b}}$, INTIMATE group ${ }^{1}$ \\ ${ }^{a}$ Centre for Quaternary Research, Department of Geography, Royal Holloway, University of London, Egham, Surrey TW20 OEX, UK \\ ${ }^{\mathrm{b}}$ Department of Physical Geography, Utrecht University, Heidelberglaan 2, 3508 TC Utrecht, Netherlands
}

\begin{abstract}
The remit of the INTIMATE ${ }^{2}$ project of the INQUA Palaeoclimate Commission is to synthesise marine, terrestrial and ice-core data for the North Atlantic region during the Last Glacial-Interglacial Transition (LGIT: ca $13-10^{14} \mathrm{C}$ kyr BP; ca $15-11.5$ ice-core kyr BP). A major problem, however, is the difficulty of effecting correlations at a temporal resolution that are adequate for defining 'leads' and 'lags' between the polar ice, terrestrial, marine, and atmospheric realms. The limitations of the dating and correlation methods currently employed are summarised, and new quality assurance protocols are proposed. These include recommendations on the contextual information that should accompany radiocarbon dates, procedures for radiocarbon calibration, the use of an eventstratigraphic approach in inter-regional correlations, and the more widespread use of time-parallel marker horizons (based on tephra layers, oxygen isotope stratigraphy, palaeomagnetic stratigraphy, and radiocarbon 'wiggle-matching') to underpin the geochronology and correlation of events during the LGIT. These protocols will be adopted by the INTIMATE project in future international, collaborative research and are recommended to other groups working on this important time period. (C) 2001 Elsevier Science Ltd. All rights reserved.
\end{abstract}

\section{Introduction}

The 4th International Workshop of the INTIMATE Project was held in Kangerlussuaq, Greenland in August 2000, the principal objective of which was to compare regional palaeoclimatic reconstructions for the Last Glacial-Interglacial Transition (LGIT: ca. $13-10{ }^{14} \mathrm{C}$ kyr BP; ca. 15-11.5 ice-core kyr BP) on a common timescale. This exercise was based on agreed procedures, the two most important being: (a) that each site record or regional scheme should be based on an independent, site-specific chronology, and (b) that the temporal resolution of each

\footnotetext{
* Corresponding author. Tel.: + 44-1784-443-565; fax: + 44-1784472-836.

E-mail addresses: j.lowe@rhul.ac.uk (J. John Lowe), w.hoek@geog.uu.nl (W.Z. Hoek).

${ }^{1}$ See Table 1 .

${ }^{2}$ Integration of Ice-core, Marine and Terrestrial Records (INTIMATE) is a core programme of the International Quaternary Union (INQUA) Palaeoclimate Commission.[INTIMATE @ http:// www.geog.uu.nl/fg/palaeoclimate/intimate.]
}

record should be sufficient to form the basis for precise inter-site and inter-regional correlation. Condition (a) was designed to exclude those records where dating was by reference to conventional stratigraphic schemes (e.g. Mangerud et al., 1974), while the temporal resolution required by condition (b) was not specified, but attention was focussed largely on individual age estimates with uncertainty of less than a century. The group analysed regional data sets from Europe, from the S.E. USA, and from the North Atlantic and Nordic seas, and these were compared with the Greenland ice-core records for the LGIT.

In practice, the exercise proved extremely difficult because of (i) limitations in the geochronological methods, especially in radiocarbon dating; (ii) lack of standardisation in procedures, particularly the calibration of radiocarbon data sets; (iii) uncertainties over the Greenland ice-core chronologies for the LGIT; and (iv) misunderstandings of the Event Stratigraphy approach advocated by Björck et al. (1998) and Walker et al. (1999). Here we summarise the problems that the INTIMATE group faced, attempt to clarify some of the issues, and 
recommend a protocol that should lead to a more secure basis for future inter-regional comparisons.

\section{Limitations on the correlation of regional data sets for the LGIT}

\subsection{Radiocarbon dates}

The majority of records for the LGIT obtained from marine and terrestrial sequences have been dated using the radiocarbon method. The robustness of these chronologies, in terms of precision and accuracy, depends upon (a) the number of radiocarbon dates available for each sequence, (b) the quality assurance procedures that underlie sample selection and sample treatment prior to radiocarbon measurement, (c) the nature of the samples dated (bulk sediment, organic carbon content, selected fossils or chemical fractions, etc.), and (d) the analytical precision achieved by the dating laboratory.

The differences in quality of radiocarbon dates can be illustrated by two hypothetical extreme cases. In the first, only a small number of radiocarbon dates (say 4 or 5) are available for the sediment sequence; the dates have been obtained from bulk sediment samples, the physical and chemical nature of which is not known and/or is inadequately described; the treatment of the samples between collection and radiocarbon measurement is little more than routine and/or is poorly described; and the standard errors on the dates are large $( \pm 100 \mathrm{yr}$ or greater). In such a case, it is difficult to assess the accuracy of the dates, to isolate aberrant dates (resulting e.g. from in situ taphonomic or biogeochemical processes, field contamination, and/or laboratory contamination), and therefore to obtain realistic calibrated age estimates (see Section 2.3). In the second case, a large number of dates has been obtained; an assessment of the radiocarbon 'inventory' in each sampled horizon has been undertaken (e.g. by comparing dates obtained from different fossil types and different chemical fractions of the fine sediment matrix in each sampled horizon); stringent pretreatment procedures have been adopted at all stages of sample preparation and analysis, and these are clearly described; and samples of relatively high organic carbon content have been obtained resulting in a high level of analytical precision (ca. $\pm 50 \mathrm{yr}$ or better). In this instance, problematic samples or types of dated material can be identified (e.g. Turney et al., 2000; Walker, in press) in the form of date inversions and/or deviating trends with respect to the bulk of the data. Furthermore, such a data set provides a more secure basis for calibration exercises (e.g. Gulliksen et al., 1998; Birks and Ammann, 2000; Birks et al., 2000 see Section 5.3). Unfortunately, the vast majority of published chronologies for sequences spanning the LGIT have closer affinities with the first hypothetical case than with the second.
From the Quaternary scientist's point of view, the most important prerequisites in the construction of a coherent ${ }^{14} \mathrm{C}$ chronology are (a) the integrity of the sampled material and (b) the development of protocols which assure maintenance of integrity during field sampling and laboratory pretreatment. If the sample material is itself suspect (i.e. has been affected by in situ contamination) or if contamination is introduced (no matter how minor) in the field or in the laboratory, then any further manipulation of the data (e.g. calibration) can only lead to spurious results. Lowe and Walker (2000) have reviewed the procedures that need to be adopted when attempting to construct a radiocarbon chronology for records of the LGIT, and have suggested the type of information that should be provided in order that the reliability of published chronologies can be assessed by others (Table 1). One of INTIMATE's aims is to develop and refine these procedures in order to provide a template for future work.

\subsection{Marine reservoir effects}

Fossils obtained from marine sequences are subject to an 'apparent age', or marine reservoir effect, caused by the slow mixing of ocean waters, and the upwelling of ${ }^{14} \mathrm{C}$-depleted waters near some coasts (Aitken, 1990). Radiocarbon laboratories apply corrections to dates obtained from marine fossils, these correction factors being derived from measurements of ${ }^{14} \mathrm{C}$ activity in contemporary marine organisms from the part of the ocean from which the fossil material was obtained. The modern reservoir effect in near-surface waters at the present time generally varies between approximately 200 and more than $750{ }^{14} \mathrm{C}$ yr (Lowe and Walker, 2000; Reimer and Reimer in press; visit $h t t p: / / w w w . c a l i b . o r g$ for access to global database of marine reservoir corrections). It is common practice to apply a standard, regional correction factor for all marine-based radiocarbon dates from the LGIT. Thus, for example, Asioli et al. (this volume) apply a correction factor for the Central Adriatic of $570{ }^{14} \mathrm{C}$ yr, while a standard correction of $400{ }^{14} \mathrm{C}$ yr is commonly applied to sequences from the NE Atlantic and Nordic seas (e.g. Eiríksson et al., 2000).

However, it is now clear that the marine reservoir effect has not remained constant throughout the LGIT. This is due partly to variations in the ocean carbon reservoir as a result of changes in both deep ocean and ocean surface conditions (Björck et al., 1996; Hughen et al., 1998a, b; Alley and Clark, 1999; Kanfoush et al., 2000), and partly to variations in the concentration of radiocarbon in the atmosphere (Kitagawa and van der Plicht, 1998a, b; Goslar et al., 2000; Stephens and Keeling, 2000). Experimental evidence has shown that marine surface reservoir ages were twice as large as those at the present time at approximately $11.9{ }^{14} \mathrm{C}$ ka BP in the S.W. Pacific Ocean (Sikes et al., 2000) and at about $10.5{ }^{14} \mathrm{C}$ ka 
Table 1

List of participants in the INTIMATE Kangerlussuaq Workshop (August, 2000) and contributors to this article

C. Andersen, Norwegian Polar Institute, Troms $\varnothing$ Norway

O. Bennike, Geological Survey of Denmark and Greenland, Copenhagen, Denmark

H.H. Birks, University of Bergen, Botanical Institute, Bergen, Norway

S. Björck, Lund University, Department of Quaternary Geology, Lund, Sweden

S.J.P. Bohncke, Vrije Universiteit, Dept. Quat. Geol. and Geomorphology, Amsterdam, The Netherlands

J.A.A. Bos, Goethe Universität, Seminar für Vor- und Frühgeschichte, Frankfurt, Germany

G.R. Coope, Royal Holloway, University of London, Department of Geography, Egham, UK

J. Eiríksson, University of Iceland, Science Institute, Reykjavik, Iceland

M. Hald, University of Troms $\varnothing$, Department of Geology, Troms $\varnothing$, Norway

V.A. Hall, Queen's University, Institute of Irish Studies, Belfast, Northern Ireland (UK)

D. Hammarlund, Lund University, Department of Quaternary Geology, Lund, Sweden

J. Heinemeier, University of Århus, AMS ${ }^{14} \mathrm{C}$ Dating Laboratory, Århus, Denmark

W.Z. Hoek, Vrije Universiteit, Dept. Quat. Geol. and Geomorphology, Amsterdam, The Netherlands

S.J. Johnsen, University of Copenhagen, Department of Geophysics, Copenhagen

K.-L. Knudsen, University of Århus, Department of Earth Sciences, Århus, Denmark

N. Koç, Norwegian Polar Institute, Troms $\emptyset$, Norway

T. Litt, University of Bonn, Institute of Paleontology, Bonn, Germany

J.J. Lowe, Royal Holloway, University of London, Department of Geography, Egham, UK

F. Marret, University of Wales, School of Ocean Sciences, Bangor, Wales (UK)

N. Noe-Nygaard, University of Copenhagen, Geological Institute, Copenhagen, Denmark

M. Prins, Vrije Universiteit, Dept. Palaeoecology and Paleoclimatology, Amsterdam, The Netherlands

B. Ringberg, Stockholm University, Department of Quaternary Research, Stockholm, Sweden

P. Schoeneich, Institut de Géographie, Université de Lausanne, Switzerland

M-S. Seidenkrantz, University of Arrhus, Department of Earth Sciences, Århus, Denmark

J.-P. Steffensen, University of Copenhagen, Department of Geophysics, Copenhagen, Denmark

C.S.M. Turney, Royal Holloway, University of London, Department of Geography, Egham, UK

B. van Geel, University of Amsterdam, Faculty of Science, Amsterdam, The Netherlands

M.J.C. Walker, University of Wales, Department of Geography, Lampeter, Wales (UK)

S. Wastegård, Stockholm University, Department of Quaternary Research, Stockholm, Sweden

W.A. Watts, University of Dublin, Trinity College, Dublin, Ireland

B. Wohlfarth, Lund University, Department of Quaternary Geology, Lund, Sweden

BP in the North Atlantic (Bard et al., 1994; Austin et al., 1995). According to Voelker et al. (1998), the magnitude of the reservoir effect in the Iceland and Norwegian Seas may have varied even more dramatically over the past $50{ }^{14} \mathrm{C}$ ka BP, by as much as $1600{ }^{14} \mathrm{C} \mathrm{yr}$, probably as a result of variations in geomagnetic field intensity, coupled with ocean circulation changes.

Clearly, the apparent age of surface marine waters has not been constant over time, and further work is urgently required to establish the magnitude and timing of temporal variations in marine reservoir effects for different ocean sectors. At present, this remains one of the major limitations on the correlation of marine and terrestrial records, for the uncertainties associated with age estimates based on marine fossils can be well in excess of the analytical precision of the ${ }^{14} \mathrm{C}$ dates themselves. Moreover, the significance of these spatial and temporal variations in the ocean carbon reservoir extends beyond the dating of marine fossils, for the ${ }^{14} \mathrm{C}$-calibration curve for the LGIT (see below) is still based largely on marine records.

\subsection{Radiocarbon calibration}

A precise ${ }^{14} \mathrm{C}$-calibration curve based on dendrochronologically dated samples is presently available only for the last ca. 12,000 dendro-years (Kromer et al., 1998; Spurk et al., 1998; Friedrich et al., 2001), which extends into the Younger Dryas Chronozone ( see Mangerud et al., 1974) or Greenland isotope stage GS-1 ( see Björck et al., 1998). Beyond that date, radiocarbon calibration is based on paired U-series and ${ }^{14} \mathrm{C}$ dates on coral samples (Bard et al., 1998; Burr et al., 1998), on ${ }^{14} \mathrm{C}$ dating of fossils contained in, or bulk sediment samples obtained from, annually laminated lake and marine sediments (Hughen et al., 1998a, b; Kitagawa and van der Plicht, 1998a,b), or on synchronisation or 'tuning' of ${ }^{14} \mathrm{C}$-dated marine or terrestrial sequences to ice-core records (Voelker et al., 1998).

The approach most widely employed to calibrate radiocarbon age estimates older than 12,000 dendroyears BP, INTCAL98, is based on the first two of these data sets (Stuiver and van der Plicht, 1998). The U-series dated coral samples that have been used as a basis for calibration, however, are limited in number and have relatively large statistical errors. Furthermore, a standard reservoir age of $400 \mathrm{yr}$ has been used in the calculation of the marine radiocarbon ages (Stuiver et al., 1998 - note that the published maximum of $500 \mathrm{yr}$ is a publication error - M. Stuiver, pers comm.). Not surprisingly, therefore, the radiocarbon calibration curve for the LGIT is far from precise, with the extent of the age 


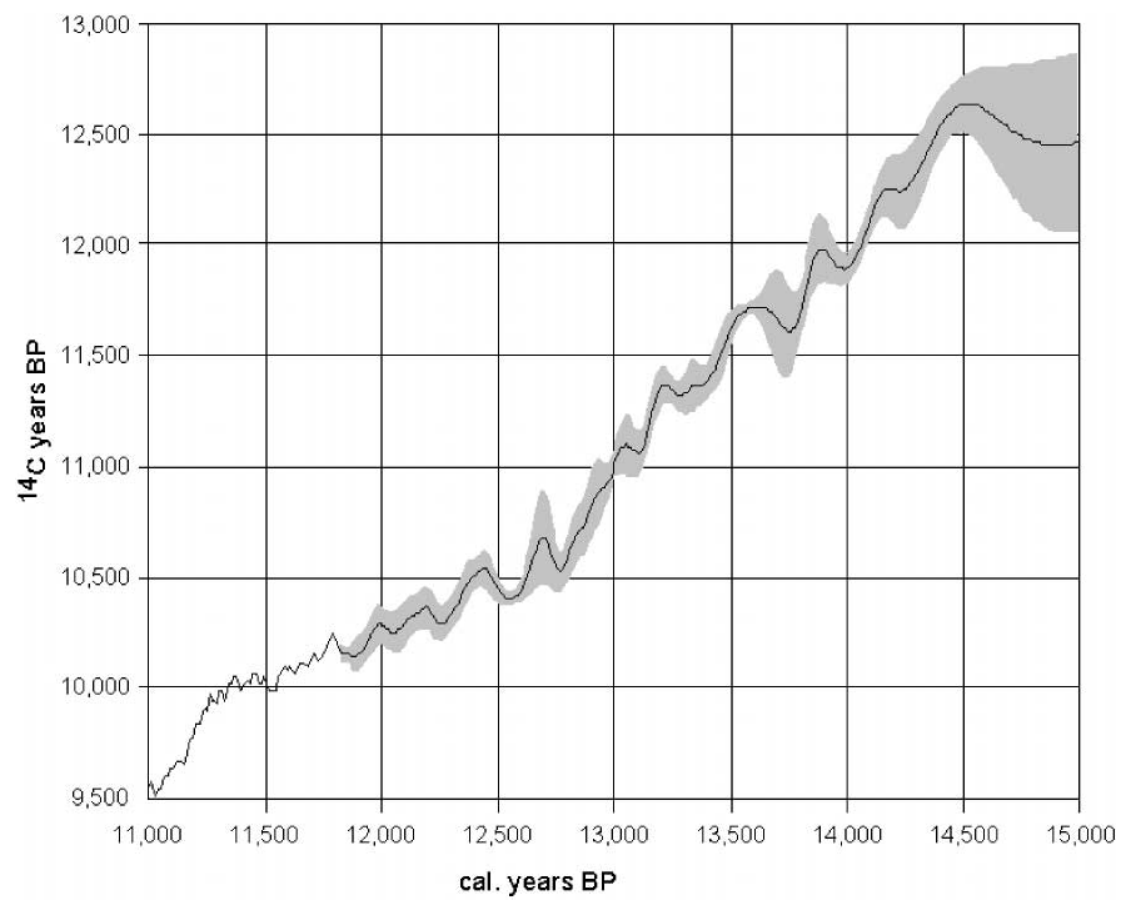

Fig. 1. The INTCAL98 calibration curve for $9500-13000{ }^{14} \mathrm{Cyr}$ BP — shaded areas are the uncertainty ranges (based on Stuiver et al., 1998).

uncertainties varying markedly throughout the time span (Fig. 1). These problems are compounded by temporal variations in atmospheric ${ }^{14} \mathrm{C}$. Because of reductions in atmospheric ${ }^{14} \mathrm{C}$ concentration, near-constant ${ }^{14} \mathrm{C}$ ages ('plateau-effects') are obtained from samples whose true (calendar) ages vary over several centuries, as for example radiocarbon ages of 10,000 or $12,700{ }^{14} \mathrm{C}$ yr BP (see Fig. 1). In only a few limited sectors of the calibration curve do plots of radiocarbon ages give a limited range of possible calendar ages, which explains why, for samples of LGIT age, calibration to INTCAL98 often significantly reduces, rather than improves, age precisions. There is a particular problem over the dating of the beginning of the LGIT in terrestrial and marine sequences, since the error margins are increasingly broad for samples with calendar ages exceeding $14,500 \mathrm{cal}$ yr BP (Fig. 1). There is clearly, therefore, a primary need to increase the number of dated coral samples or, better still, to extend the dendro-calibration curve back in time in order to establish a more secure basis for calibrating radiocarbon chronologies for the LGIT.

One approach which potentially offers a basis for dating events more precisely involves 'wiggle-matching'of radiocarbon data sets to the radiocarbon calibration curve. This technique has been employed with some success by Gulliksen et al. (1998) for the dating of the Greenland Stadial 1/Holocene transition in Norway, and by van Geel et al. (1996), Kilian et al. (2000) and Speranza et al. (2000) for the dating of Holocene events. The methodology is based on the principle that 'wiggles' in the calibration curve (plateaux and steep transitions) should be reflected in time-depth fluctuations in radiocarbon dates obtained from stratified sequences, and that the latter can be matched to the former to derive calendar ages for the radiocarbon-dated horizons. However, this approach requires a large number of radiocarbon dates for confident matching to the calibration curve. Gulliksen et al. (1998), for example, obtained 70 AMS radiocarbon dates to establish a close match to the part of the calibration curve which spans the Greenland Stadial $1 /$ Holocene boundary. Relatively few dating series from the LGIT approach this degree of resolution, but those which do appear to replicate some of the pronounced shifts ('wiggles') in the radiocarbon calibration curve (e.g. Ammann and Lotter, 1989; Björck et al., 1996; Andresen et al., 2000), which suggests that radiocarbon 'wiggle-matching' may provide a basis for improved correlation of LGIT sequences. At present, the available data for the LGIT do not provide the degree of precision that 'wiggle-matching' to the dendro-based calibration curve makes possible for the dating and correlation of Holocene events, though this situation may improve in the near future, as progress is made in extending the tree-ring chronologies back into Greenland Interstadial 1 (Friedrich et al., 2001).

Given this background, one question that emerges is whether it would be better in future to channel resources towards the generation of high-resolution radiocarbon data sets from carefully selected, key regional sequences, rather than dilute them by supporting a larger number of more limited investigations. In cases where a small number of radiocarbon dates is available for a sequence 
which spans the LGIT, especially if the dates are based on bulk sediment samples, the uncertainties will be so large as to render the results of 'rangefinder' value only. For certain parts of the world, where the broad geochronological context is already well established (e.g. much of Europe), it is doubtful whether such an approach would add little more to age estimation than can be satisfactorily achieved by biostratigraphical or isotope stratigraphic correlation (see e.g. Schwander et al., 2000; Brooks and Birks, in press; Hoek and Bohncke, 2001). For LGIT sequences, therefore, radiocarbon dating can only provide increased precision if high-resolution data sets are generated, the robustness of the data are tested rigorously, sufficient data are generated to attempt 'wiggle-matching' to the INTCAL98 calibration curve (or its successor), and independent tests of their accuracy can be conducted.

\subsection{Greenland ice-core records}

The principal objective of the INTIMATE project is to compare marine and terrestrial records for the LGIT with the very detailed ice-core records obtained from the Greenland Summit, in order to test current ideas about 'leads' and 'lags' in the North Atlantic climate system. For this purpose, the INTIMATE group recommended that the appropriate segment of the GRIP record be adopted as the type profile for this time period (Björck et al., 1998; Walker et al., 1999). It should be stressed that this decision was not intended to imply that the GRIP chronology was demonstrably more accurate for the LGIT interval than the GISP-2 chronology. The proposal was made to establish a standard timescale, against which all other independently constructed schemes could be compared, in order to bring consistency to the exercise. Brief reference was made by Björck et al. (1998, p. 287) to the fact that alternative Greenland chronologies exist, but the matter perhaps requires some clarification.

There are currently three Greenland chronologies frequently employed in compilations for the LGIT (Fig. 2): a GISP-2 chronology (Bender et al., 1994; Meese et al., 1997), an 'official' GRIP chronology (ss09 - the original GRIP chronology - which is available on the Web - Hammer et al., 1997; Johnsen et al., 1997), and a revised GRIP chronology, ss08c, made available to the INTIMATE project members at the 1997 INTIMATE workshop held in Höör, Sweden by S. Johnsen, and subsequently published in Von Grafenstein et al. (1999). A new high-frequency (3-yr resolution) chronology has recently become available for the GISP-2 core (Stuiver and Grootes, 2000). This shows the isotope variations of the GISP2 'official' record (Fig. 2) in greater detail, but does not substantially alter the estimated ages of the main climatic oscillations reflected in the record.) GRIP chronology ss08c was adopted by INTIMATE as the

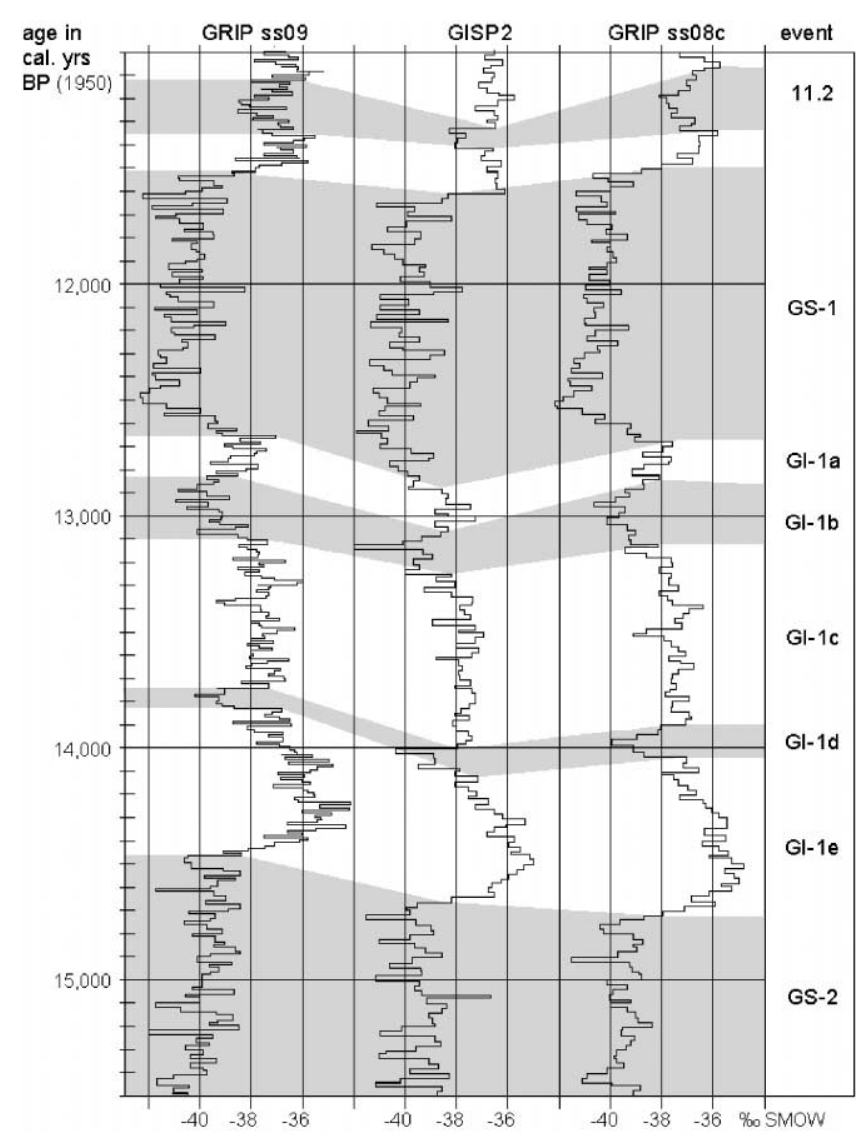

Fig. 2. Greenland ice-core chronologies (based on oxygen isotope variations) for the Last Glacial-Interglacial Transition - the colder episodes are shaded. GISP2 and GRIP ss09 are the published records from these core sites. GRIP 'INTIMATE' is an unpublished data set, explained in the text. The Event column (right-hand edge) refers to the INTIMATE Event Stratigraphy of Björck et al. (1998) and Walker et al. (1999). The horizontal lines are the boundaries for the events, defined with respect to the GRIP ss08c chronology. The GISP2 and GRIP data have been provided by the National Snow and Ice Data Centre, University of Colorado at Boulder, and the WDC-A for Palaeoclimatology, National Geophysical Data Centre, Boulder, Colorado.

standard Greenland chronology, because, at that time, it was the most detailed Greenland isotope profile available for the LGIT, with the dating of the core based on annual layer counting back to $14.7 \mathrm{kyr}$ BP. There are important differences between all three schemes, the divergence in ages of individual LGIT events being as much as $200 \mathrm{yr}$ (Fig. 2), though there are less marked differences between them (at most $100 \mathrm{yr}$ ) for the age of the start of the Holocene (dated to ca. 11.5/11.6 k ice-core yr BP). Given the apparent abruptness of climatic changes during the LGIT, it is clearly important to resolve these differences, in order that the degree of correlation between marine, terrestrial and ice-core records, and hence the scales of any 'leads' and 'lags' between them, can be precisely defined. 
In practise, it matters little which of these chronologies is selected as a standard for comparison, so long as it is clearly identified, and the differences in estimated ages of events suggested by the other reconstructions are acknowledged or taken into account when correlations are proposed between marine, terrestrial and ice-core records. At some stage a consensus will almost certainly emerge as to which is the most reliable Greenland chronology, at which point a new standard will be more universally recognised, and all previous age estimates and comparisons can then be easily re-calculated. The INTIMATE group is therefore of the opinion that there is insufficient justification for changing the adopted stratotype at this juncture. A new and more detailed chronology for the LGIT will shortly become available, based on samples obtained from the new NGRIP coring site located (at $75^{\circ} \mathrm{N}$ ) some $30 \mathrm{~km}$ to the north of the original GRIP borehole (Dahl-Jensen et al., 1998). Drilling commenced in 1996, and achieved a depth of $1750 \mathrm{~m}$ in 1999 , and $2900 \mathrm{~m}$ in 2000 . Very clear and complete records for the Holocene and last glacial stage have been obtained. A preliminary isotope profile for the LGIT from NORDGRIP samples collected in summer 2000 shows a remarkable similarity to the GRIP ss09 record, though detailed counting is not yet complete. NGRIP will be counted to an annual resolution, and is likely to yield the most detailed ice-core chronology for the LGIT. The INTIMATE group therefore resolved to continue to use the GRIP ss08c chronology to underpin the Event Stratigraphy for the LGIT until the new NGRIP chronology becomes available.

\subsection{Event Stratigraphy}

There has been some confusion over the INTIMATE proposal for an Event Stratigraphy for the N. Atlantic region, based on the stratotype of the GRIP ice-core record (Björck et al., 1998; Walker et al., 1999). This scheme defines a series of stadials and interstadials for the period 23.0-11.5 ice-core yr BP, based on marked oxygen isotope variations in the GRIP ice core. Some of these episodes are further sub-divided into sub-stadial or subinterstadial episodes. Collectively, they constitute a series of events spanning the LGIT, the ages of which have been derived from the GRIP ss08c chronology (Table 2 in Björck et al., 1998). However, it was never intended that this scheme should replace local or regionally based stratigraphic schemes and chronologies (as seems to have been assumed in some quarters). Such an approach would simply duplicate the problems that arose in the application of the Mangerud et al. (1974) scheme, which was rarely applied strictly in the manner intended (i.e. as a chronostratigraphic standard), and which unintentionally promoted a terminology ('Bølling', 'Allerød', etc.) which was stratigraphically ambiguous (Björck et al., 1998).
The INTIMATE Event Stratigraphy scheme has been proposed as a standard against which to compare regional stratigraphic schemes, and as a basis for establishing the synchroneity (or asynchroneity) of comparable events or sequences of events throughout the North Atlantic region. The approach is exemplified in the papers by Asioli et al. (this volume) and Hoek and Bohncke (in press) where events have been defined and dated independently for the Central Adriatic and The Netherlands, respectively, and then compared with the GRIP Event Stratigraphy. In this case the evidence suggests apparent age differences between local climatic/environmental events and what are considered to be comparable events in the GRIP record. By contrast, evidence from several sites in Switzerland suggests a broad measure of synchroneity between local climate events in Switzerland and those in Greenland, as reflected in the GRIP ss08c chronology, for the period between 13.5 and $10.5{ }^{14} \mathrm{C}$ cal yr BP (Schwander et al., 2000). Since a common standard has been used, this implies that there were important differences in the timing of climate/environmental changes between Switzerland and the Adriatic, though this hypothesis needs to be examined more fully, with tighter geochronological controls.

The adoption of the Greenland ice-core record as the stratotype for the LGIT, and thus as the standard chronology against which to compare the timing of regional events, has some advantages over the use of the traditional scheme of Mangerud et al. (1974) (see Wohlfarth, 1996; Björck et al., 1998). The ice cores record the sequence of events at the highest available temporal resolution (potentially definable to sub-annual variations) and the chronologies derived from them, although not free of problems, are less problematic than radiocarbon dates, especially because several of the key transitions lie within radiocarbon plateaux. Extension of the dendrochonologically based radiocarbon calibration further back into the LGIT should reduce the uncertainties in radiocarbon calibration, but this may not be achieved for some years yet. However, an extended calibration curve based on dendrochronology will provide only a limited improvement, since the radiocarbon plateaux will remain, and calibrations of radiocarbon measurements at $2 \sigma$ intervals will have uncertainties of several decades at best, and several centuries in many cases. Thus, such a step will not remove the need for a high-precision ice-core chronology as an independent standard for inter-regional correlations.

\subsection{Varve chronologies of the Last Glacial-Interglacial Transition}

An alternative, independent means of establishing the precise ages and durations of events on land or in the oceans during the LGIT is by counting of annually laminated sediment sequences. A number of such records 
are available from several parts of Europe including, for example, Lakes Gosciaz and Perespilno in Poland (Goslar et al., 1992, 1993, 1999), several former and extant lakes in Germany (e.g. Hajdas et al., 1993, 1995a; Zolitschka et al., 2000; Litt et al., 2001) and Lago Grande di Monticchio in southern Italy (Huntley et al., 1999). Correlations between these varved sequences can be established by radiocarbon dating, geomagnetic (palaeosecular) stratigraphy and tephrochronology (see Zolitschka, 1999).

Litt et al. (2001) provide a table comparing the ages of local events and their boundaries in the Eifelmaar region with comparable events in Lower Saxony and Poland, and with the GRIP (INTIMATE) Event Stratigraphy. While precise comparisons are presently mostly limited to the later parts of GI-1 and to GS-1, this nevertheless illustrates the potential of such varved sequences, for establishing the timing and duration of climatic events in key sites in Europe, and thereby establishing the degree of synchroneity (or otherwise) of these events at a continental scale. Analysis of an almostcomplete sequence of varved sediments from Holzmaar (Germany) spanning the last ca. $23 \mathrm{kyr}$, for example, is in closer agreement with GISP2 than GRIP records with respect to estimated ages of, for example, the marked climatic warming at the start of GI-1 (Zolitschka et al., 2000).

There are, however, uncertainties associated with the varve chronologies. These include: (a) the problem of defining the timing of abrupt, regional climatic changes as opposed to local environmental responses to them (especially since few of the climatic events have been defined in quantified terms); (b) some of the varved sequences, such as Perespilno and Gosciaz, have been 'synchronised' or 'tuned' to each other, so that synchroneity of events is assumed rather than independently tested, (c) several of the sequences are known to have been interrupted by hiatuses of unknown duration; and (d) most do not extend to the present-day, and hence the chronologies are essentially 'floating' and cannot be directly connected to the calendar timescale, but rely on the radiocarbon 'wiggle-matching' approach. Furthermore, even where it can be established that local varve chronologies are reliable, they provide a precise chronology for local events only, but there remains the problem of establishing the age of events in areas where laminated sequences are absent.

\subsection{Tephrochronology}

Individual tephra layers that can be identified in sediment sequences and which can be shown to have originated from the same volcanic event represent timeparallel marker horizons. Until recently, the analysis of tephras of LGIT age in the North Atlantic region was confined to visible tephras, such as the Vedde Ash in
Norway and the NE Atlantic (of Icelandic origin, and dated to $10.4-10.3{ }^{14} \mathrm{C}$ ka BP - Mangerud et al., 1984; Kristiansen et al., 1988; Björck et al., 1992; Birks et al., 1996) and the Laacher See Tephra (originating from the Eifel district of Germany, and dated to ca. 11.0-11.2 ka ${ }^{14} \mathrm{C}$ BP — van den Bogaard and Schminke, 1985; Hajdas et al., 1995b; Friedrich et al., 1999; Leroy et al., 2000; Litt et al., this volume). In the last few years, however, microtephra horizons not visible to the naked eye have been detected in a number of sites in northern Europe, greatly extending the area over which the Vedde Ash, for example, has been traced (e.g. Turney et al., 1997; Wastegård et al., 1998, 2000). This, in turn, has significantly increased the potential for high-precision correlations between terrestrial, marine and ice-core records, since the Vedde Ash has been discovered in a number of marine sequences (Bond et al., 2001), as well as in the GRIP ice core, where it has been dated to ca. $12.0 \mathrm{ka}$ GRIP icecore yr BP (Grönvold et al., 1995). It is possible that several other micro-tephra horizons remain to be detected, as suggested by the discovery of the Borrobol Tephra (which dates to the early part of Greenland isotope event GI-1e) in sites in northern Britain (Turney et al., 1997) as well as in cores obtained from the marine shelf to the north of Iceland (Eiríksson et al., 2000). The recent reporting of 9 new basaltic tephra layers for the LGIT from Iceland (Haflidason et al., 2000) raises the possibility that some of these may also be detectable in marine and terrestrial sequences in the North Atlantic region.

Tephrochronology therefore offers a basis not only for dating events during the LGIT, but it also constitutes an important means of correlation between marine, terrestrial and ice-core records. In addition, it may enable estimates to be made of temporal variations in marine reservoir ages, and hence may help reduce errors in ${ }^{14} \mathrm{C}$ dates (Lowe, in press; Turney et al., in press).

\section{The INTIMATE Protocol for high-precision correlation of palaeoclimatic records from the Last Glacial-Interglacial Transition}

In the light of the problems outlined above, the INTIMATE group is of the view that new guidelines are now required in order that the dating and correlation of records of the LGIT can be undertaken with a higher degree of precision than has been possible hitherto. A first attempt at drawing up these guidelines is presented below, and is designed to encourage wider consideration of the issues and to invite suggestions for modifications or additions. Adherence to the guidelines should ensure: (a) the publication of more detailed information about the data used to construct site chronologies for the LGIT; (b) more accurate site and/or regional chronologies; and, (c) a more rigorous approach to inter-regional correlation. The outcome should be 
a more secure time-stratigraphic framework for data syntheses at regional or hemi-spherical scale.

The immediate aims are two-fold: (1) to use all available site and contextual information to 'screen' published dates according to agreed quality assurance criteria (see below); and (2) to produce new dates at the highest possible levels of accuracy and precision in line with these protocols. Dates generated under (1) and (2) should be archived and, where necessary, amended as new correction factors become available (e.g. revised estimates of marine reservoir errors), or recalibrated as new calibration data sets are developed.

\subsection{Contextual information for site chronologies}

All geochronological data sets should be published with appropriate contextual information concerning the nature of the samples selected for dating, treatment of the samples prior to and during age measurement, and any correction factors employed in the calculation of the individual age estimates. Authors should aim to address as many of the criteria listed in Table 2 as is possible. As a minimum, the following information should always be supplied, for each age measurement reported:

- nature of material(s) selected for dating,

- precise stratigraphic position of each sample selected for dating,

- date of collection of materials and date of supply to the dating laboratory,

- dating laboratory's sample codes,

- treatment of samples prior to submission to the dating laboratory,

- type of measurement conducted by laboratory (AMS, radiometric) and note of any non-routine pretreatment procedures adopted (e.g. separation of humic fraction),

- statement of any correction factors applied in age calculation (e.g. marine reservoir correction).

In any research paper, this information could be provided compactly in the appendix using a smaller font. Alternatively, authors could make the information available via the Internet, though this is less desirable, for the information may be lost to the scientific community if the electronic files and ready access are not maintained. It is vital that all 'primary' age measurements and associated contextual information are published, along with any manipulations of the data, such as calibrated age measurements. Whereas correction factors and calibration methods may change in the future, the original radiocarbon measurements will retain their validity, assuming that certain quality assurance criteria are satisfied. It is the original data, therefore, that will be used for recalculations and re-calibrations, and which it is therefore vital to capture within appropriate databases.

\subsection{Calibration of radiocarbon dates}

All radiocarbon age measurements for events and materials of LGIT age should be calibrated using INTCAL98 (the recommendation of Stuiver et al., 1998) in order to standardise data and facilitate comparisons. Back to ca. $10.3{ }^{14} \mathrm{C}$ ka BP (close to the Vedde Ash, mid-GS1), the calibration curve is in close agreement with both GISP2 and GRIP chronologies. For the section older than $10.3{ }^{14} \mathrm{C}$ ka BP, INTCAL98 is based on Cariaco (marine) dates, that are in agreement with the GISP2 reconstruction. It is important to remember that the GRIP ss09 reconstruction diverges by up to $200 \mathrm{yr}$ (younger) from GISP2 in this portion of the records.

All calibrated age measurements should make reference to the conversion procedures adopted, and this should include a note of the program used (e.g. CALIB4.0), as well as the option selected for interpreting the calibrated age probability distribution suggested by the program. Particular difficulties arise, however, where the radiocarbon age intersects with the calibration curve at more than one point (e.g. at $10,000{ }^{14} \mathrm{C} \mathrm{yr} \mathrm{BP} \mathrm{—} \mathrm{Fig.} \mathrm{1)}$ as this generates two or more probability ranges. One approach adopted by some has been to use the highest probability range only, and to take the mid-point of that range, while others have averaged the several probability ranges suggested for each radiocarbon date. Since calibration ranges are not symmetrical, the approach which best represents the full uncertainties in calibrated dates is one which takes account of the full range and not a mean value. For now, however, the INTIMATE recommendation is always to quote the procedure adopted, and to provide in a table or appendix the probability ranges generated for each date, so that the full extent of the uncertainties involved in the calibrations is evident.

There is clearly a need to reduce the uncertainties of calibrations to a minimum, at least until such time as a more precise calibration curve becomes available. There appear to be three possible ways of achieving this:

\subsubsection{Wiggle-matching}

Although the uncertainty bands in INTCAL98 are frequently wide, there is a degree of structure in the form of plateaux separated by steeper parts, and these may well be reflected in detailed dating series (Fig. 1). If one or more of these features can be confidently replicated in regional or site radiocarbon chronologies, then this may provide a reliable basis for correlation. More effort should therefore be expended in attempts to 'wigglematch' to the calibration curve in the manner adopted for Late-Glacial and early Holocene sequences by Goslar et al. (2000) and for Holocene sequences by Gulliksen et al. (1998), van Geel et al. (1996) and Kilian et al. (2000) (Section 2.3), for this greatly reduces the uncertainties of calibrations. This approach will require a far greater number of radiocarbon measurements than has tended to 
Table 2

Issues to be considered in the design of laboratory protocols and reporting of radiocarbon dates for high-precision correlation of records of the Last Glacial-Interglacial Transition (from Lowe and Walker, 2000)

1. Sample integrity (e.g. for bulk organic sediment samples)

provider's sample number; single measurement, or part of a series of measurements ?

if 'yes', specify provider and radiocarbon lab. numbers for all other samples in series;

- information of stratigraphic (temporal) resolution of sequence from which samples have been obtained;

- nature of material dated;

- organic C content (LOI);

- carbonate content;

- nature of any clastic residue;

- wet weight of sample submitted to laboratory;

- total organic C (dry wt.) used in radiocarbon measurement;

- tests for radiocarbon activity heterogeneity of bulk material (e.g. 'humic' versus 'humin'; other fractions tested)

2. Laboratory handling (provider)

- date of collection of samples;

- date of submission of samples to radiocarbon laboratory;

- storage conditions between date of collection and date of submission;

- treatment of samples over storage period;

- nature of solvents, dispersants (etc.) used;

- conditions under which samples extracted and packaged for transfer to radiocarbon laboratory (e.g. whether under controlled air conditions);

3. Radiocarbon laboratory procedures

- date samples received;

- date samples counted;

- storage conditions between date of receipt and date of count start;

- pretreatment procedures adopted;

- formal laboratory sample number;

- count statistics;

- corrections applied (e.g. fractionation; reservoir effects);

- comments on any unusual chemical effects during pretreatment;

4. Calibration procedures applied

- calibration data-set employed (specify version - e.g. CALIB4.0);

- specify any smoothing or rounding procedures employed;

- single calibration, or part of a series of calibrations ?

- if 'yes', specify provider and radiocarbon lab. numbers for all other samples in series.

be employed in the investigation of Lateglacial sequences hitherto, especially where there is no independent time control (e.g. annually laminated sediments). The adoption of this approach is particularly recommended in the construction of chronologies for regional-type sequences.

\subsubsection{Selection of ${ }^{14} C$ ages that fall on steep parts of the INTCAL98 calibration curve}

To fix 'absolute' ages in a sequence by radiocarbon dating, the radiocarbon dates of greatest value are those that fall on steep parts of the calibration curve with small error ranges (Fig. 1). More weight can be given to these points, because the uncertainties are less. Other obvious structural features are the end-points of the radiocarbon plateaux, though these can only be identified with a high-resolution radiocarbon data set (Table 2). Targeting these points in a radiocarbon series (either by determining horizons to be dated by reference to appropriate stratigraphical markers, such as the Vedde Ash, or by selecting the appropriate radiocarbon dates from a dating series), should establish a set of fixed points for a more reliable age-depth model. This in turn may provide a basis for calculating sedimentation rates, and hence for estimating the ages of other horizons by interpolation. It is the view of the INTIMATE group that this may be a superior approach to one which simply includes all calibrations of all of the dates, some of which will have wide uncertainties.

\subsubsection{Application of Bayesian probability techniques}

More attention should be paid to the detailed probability structures in the original radiocarbon measurements and in the INTCAL98 calibration data set. The uncertainties of calibration can be reduced for a series of radiocarbon dates using, for example, a Bayesian approach to probability assessments, which incorporates prior information about stratigraphic context and 
succession of the series of dates into the analysis (e.g. Bronk Ramsey, 1999).

\subsection{INTIMATE (GRIP) Event Stratigraphy}

The Event Stratigraphy of Björck et al. (1998) and Walker et al. (1999) constitutes perhaps the most satisfactory basis for effecting inter-regional comparisons. The INTIMATE group recommends that stratigraphic sequences be described using local terms initially, and dated independently wherever possible. The climatostratigraphy and chronology of each sequence should then be compared with the GRIP stratotype (Table 3), in order to establish the degree of compatibility or otherwise with regional stratigraphic schemes. The GRIP isotope profile and chronology of Björck et al. (1998) and Fig. 2 should continue to be used as the reference standard but, in due course, this may be replaced by an alternative chronology which, by wide consensus, is considered to provide more accurate ages of events during the LGIT.

\subsection{The use of time-parallel 'marker' events}

Time-parallel events in the geological record, which provide important 'tie-lines' between marine, terrestrial and ice-core sequences, offer an alternative basis for the dating and correlation of events during the LGIT. On a regional basis, these potentially include widespread tephra layers (Turney et al., in press), marked changes in oxygen isotope ratios obtained from carbonate-rich sediments (Hoek and Bohncke, in press; Schwander et al., 2000) and geomagnetic (secular) stratigraphy
(Brandt et al., 1999). On a global basis, 'wiggle-matching' of radiocarbon data sets to marked inflections in the ${ }^{14} \mathrm{C}$ calibration curve should provide a reliable basis for inter-regional correlation, since they are likely to reflect globally synchronous changes in atmospheric ${ }^{14} \mathrm{C}$ concentration (Section 3.2). Some of the latter may, in turn, reflect abrupt solar effects, such as a sharp rise of delta ${ }^{14} \mathrm{C}$ at the start of the GS-1/Younger Dryas stadial (Renssen et al., 2000), which may have been the trigger for widespread climatic change at that time.

The INTIMATE group recommends that greater emphasis be placed upon these marker horizons in sequences of LGIT age. They may, for example, help to establish the precise relationship between varve, ice-core and radiocarbon chronologies. They may also provide an important means of determining the scale of marine reservoir effects in the past. Collectively, they may provide the basis for an over-arching framework for testing inter-site and inter-regional correlations, and hence for constructing time-space models of climate change during the last Glacial-Interglacial transition.

\section{Acknowledgements}

This paper is a contribution to the INTIMATE project of the INQUA Palaeoclimate Commission. Those wishing to collaborate within the project should contact the Secretary (Wim Hoek) or the Co-ordinator (John Lowe) at the postal/email addresses given on the title page. Note that the remit of INTIMATE is being extended to include the Mediterranean and South Atlantic regions, including the adjacent land areas.

Table 3

Examples of 'steep' sectors of the radiocarbon calibration curve (INTCAL98) and of plateau inflections (see Fig. 1) which, if pin-pointed in detailed radiocarbon chronologies, provide more precise calibrated ages. Note that Kromer (unpublished) refers to new tree-ring series from Europe which may extend the dendro-calibration back into the LGIT, and for which work is currently in progress (B. Kromer, pers. comm.; see also Friedrich et al., 2001)

\begin{tabular}{|c|c|c|c|c|c|}
\hline \multirow[b]{2}{*}{ Estimated age } & \multirow[b]{2}{*}{ Early Holocene } & \multicolumn{2}{|c|}{$\begin{array}{c}\text { Approximate stratigraphic position } \\
\text { Terminology after Björck et al. (1998) } \\
\text { and Mangerud et al. (1974) }\end{array}$} & \multirow[b]{2}{*}{$\begin{array}{l}\text { Mid-GI-1c } \\
\text { (mid-Allerød) }\end{array}$} & \multirow[b]{2}{*}{$\begin{array}{l}\text { Onset of GI-1d } \\
\text { (start of 'Older Dryas') }\end{array}$} \\
\hline & & $\begin{array}{l}\text { Mid-GS-1 } \\
\text { (mid-Younger Dryas): } \\
\text { Vedde Ash }\end{array}$ & $\begin{array}{l}\text { GI-1a/GS-1 } \\
\text { (Allerød/Younger } \\
\text { Dryas) boundary }\end{array}$ & & \\
\hline Steep point $\left({ }^{14} \mathrm{C}\right.$ age $)$ & 9800 & $10,310 \pm 50$ & 10,800 & 11,200 & 12,100 \\
\hline $\begin{array}{l}\text { Termination of }{ }^{14} \mathrm{C} \\
\text { plateau effect }\end{array}$ & 9600 & & 10,600 & 11,100 & 12,300 \\
\hline $\begin{array}{l}\text { Start of }{ }^{14} \mathrm{C} \text { plateau } \\
\text { effect }\end{array}$ & 10,000 & & 11,000 & 11,300 & 11,600 \\
\hline INTCAL98 age BP & 11,200 & $12,000-12,300$ & 12,800 & 13,200 & 14,100 \\
\hline Further details & & $\begin{array}{l}\text { 12,000 GRIP } \\
\text { ice-core yr BP }\end{array}$ & $\begin{array}{l}12,650 \text { GRIP } \\
\text { ice-core yr BP }\end{array}$ & $\begin{array}{l}\text { More details in } \\
\text { B. Kromer } \\
\text { (unpubished) }\end{array}$ & $\begin{array}{l}\text { Only detectable in new } \\
\text { B. Kromer data } \\
\text { (unpublished) }\end{array}$ \\
\hline Reference & Gulliksen et al. (1998) & Birks et al. (1996) & & $\begin{array}{l}\text { B. Kromer } \\
\text { (unpublished) }\end{array}$ & $\begin{array}{l}\text { B. Kromer, } \\
\text { (unpublished) }\end{array}$ \\
\hline
\end{tabular}




\section{References}

Aitken, M.J., 1990. Science-Based Dating in Archaeology. Longman Archaeology Series, London, New York.

Alley, R.B., Clark, P.U., 1999. The deglaciation of the Northern Hemisphere: a global perspective. Annual Review of Earth and Planetary Sciences 27, 149-182.

Ammann, B., Lotter, A.F., 1989. Late-glacial radiocarbon - and palynostratigraphy on the Swiss Plateau. Boreas 18, 109-126.

Andresen, C.S., Björck, S., Bennike, O., Heinemeier, J., Kromer, B., 2000. What do ${ }^{14} \mathrm{C}$ changes across the Gerzensee oscillation/GI-1b event imply for deglacial oscillations? Journal of Quaternary Science 15, 203-214.

Asioli, A., Trincardi, F., Lowe, J.J., Ariztegui, D., Langone, L., Oldfield, F. 2001. Sub-millennial climatic oscillations in the Central Adriatic during the Weichselian Late-glacial: paleoceanographic implications. Quaternary Science Reviews.

Austin, W.E.N., Bard, E., Hunt, J.B., Kroon, D., Peacock, J.D., 1995. The ${ }^{14} \mathrm{C}$ age of the Icelandic Vedde Ash: implications for Younger Dryas marine reservoir age corrections. Radiocarbon 37, 53-62.

Bard, E., Arnold, M., Hamelin, B., Tisnerat-Laborde, N., Cabioch, G., 1998. Radiocarbon calibration by means of mass spectrometric ${ }^{230} \mathrm{Th} /{ }^{234} \mathrm{U}$ and ${ }^{14} \mathrm{C}$ ages of corals: an updated database including samples from Barbados, Mururoa and Tahiti. Radiocarbon 40, 1085-1092.

Bard, E., Arnold, M., Mangerud, J., Paterne, M., Labeyrie, L., Duprat, J., Melieres, M.-A., Sonstegaard, E., Duplessy, J.-C., 1994. The North Atlantic atmosphere-sea surface ${ }^{14} \mathrm{C}$ gradient during the Younger Dryas climatic event. Earth and Planetary Science Letters 126, 275-287.

Bender, M., Sowers, T., Dickson, M., Orchado, J., Grootes, P., Mayewski, P., Meese, D., 1994. Climatic correaltions between Greenland and Antarctica during the past 100,000 years. Nature 372, 663-666.

Birks, H.H., Ammann, B., 2000. Two terrestrial records of rapid climatic change during the Glacial-Holocene transition (14,000-9,000 calendar years BP) from Europe. Proceedings of the National Academy of Sciences USA 97, 1390-1394.

Birks, H.H., Battarbee, R.W., Birks, H.J.B., 2000. The development of the aquatic ecosystem at Kråkenes Lake, western Norway, during the late-glacial and early Holocene - a synthesis.

Birks, H.H., Gulliksen, S., Haflidason, H., Mangerud, J., Possnert, G., 1996. New radiocarbon dates for the Vedde Ash and the Saksunarvatn Ash from Western Norway. Quaternary Research 45, 119-127.

Björck, S., Ingólfsson, O., Haflidason, H., Hallsdóttir, M., Andersson, N.J., 1992. Lake Torfadalsvatn: a high resolution record of the North Atlantic ash zone I and the last Glacial-Interglacial changes in Iceland. Boreas 21, 15-22.

Björck, S., Kromer, B., Johnsen, S., Bennike, O., Hammarlund, D., Lemdahl, G., Possnert, G., Rasmussen, T.L., Wohlfarth, B., Hammer, C.U., Spurk, M., 1996. Synchronized terrestrial-atmospheric deglacial records around the North Atlantic. Science 274, $1155-1160$.

Björck, S., Walker, M.J.C., Cwynar, L., Johnsen, S.J., Knudsen, K.L., Lowe, J.J., Wohlfarth, B., INTIMATE Members, 1998. An event stratigraphy for the last termination in the North Atlantic based on the Greenland Ice Core record: a proposal by the INTIMATE group. Journal of Quaternary Science 13, 283-292.

Bond, G.C., Mandeville, C., Hoffman, S. 2001. Were rhyolitic glasses in the Vedde Ash and in the North Atlantic's Ash Zone I produced by the same volcanic eruption? Quaternary Science Reviews.

Brandt, U., Nowaczyk, N.R., Ramrath, A., Brauer, A., Mingram, J., Wulf, S., Negendank, J.F.W., 1999. Palaeomagnetism of Holocene and Late Pleistocene sediments from Lago di Mezzano and Lago Grande di Monticchio (Italy): initial results. Quaternary Science Reviews 18, 961-976.
Bronk Ramsey, C., 1999. Oxcal. radiocarbon calibration and stratigraphic analysis program. Research Laboratory for Archaeology, Oxford University, Oxford ( (www.rlaha.ac.uk)

Brooks, S.J., Birks, H.J.B. Chironomid-inferred late-glacial air temperatures at Whitrig Bog, south-east Scotland. Journal of Quaternary Science, in press.

Burr, G.S., Beck, J.W., Taylor, F.W., Recy, J., Edwards, R.L., Cabioch, G., Correge, T., Donahue, D.J., O'Malley, J.M., 1998. A high-resolution radiocarbon calibration between 11,700 and 12,400 calendar years BP derived from $230 \mathrm{Th}$ ages of corals from Espiritu Santo Island, Vanuatu. Radiocarbon 40, 1093-1105.

Dahl-Jensen, D., Mosegaard, K., Gundestrup, N., Clow, G.D., Johnsen, S.J., Hansen, A.W., Balling, N., 1998. Past temperatures directly from the Greenland Ice Sheet. Science 282, 268-271.

Eiríksson, J., Knudsen, K.-L., Haflidason, H., Henriksen, P., 2000. Late-glacial and Holocene palaeoceanography of the North Icelandic shelf. Journal of Quaternary Science 15, 23-42.

Friedrich, M., Kromer, B., Kaiser, K.F., Spurk, M., Hughen, K.A., Johnsen, S.J. 2001. High resolution climate signals in the BøllingAllerød Interstadial (Greenland Interstadial 1) as reflected in European tree-ring chronologies compared to marine varves and ice-core records. Quaternary Science Reviews.

Friedrich, M., Kromer, B., Spurk, M., Hofmann, J., Kaiser, K.F., 1999. Paleo-environment and radiocarbon calibration as derived from Lateglacial/Early Holocene tree-ring chronologies. Quaternary International 61, 27-39.

Goslar, T., Arnold, M., Tisnerat-Laborde, N., Czernik, J., Wieckowski, K., 2000. Variations of Younger Dryas atmospheric radiocarbon explicable without ocean circulation changes. Nature 403, 877-880

Goslar, T., Balaga, K., Arnold, M., Tosnerat, N., Starnawska, E., Kuzniarski, M., Chróst, A., Walanus, A., Wieckowski, K., 1999. Climate-related variations in the composition of the Lateglacial and Early Holocene sediments of Lake Perespilno (eastern Poland). Quaternary Science Reviews 18, 899-912.

Goslar, T., Kuc, T., Pazdur, M.F., Ralska-Jasiewiczowa, M., Rozanski, K., Szerozynska, K., Walanus, A., Wicik, B., Wieckowski, K., 1992. Possibilities for reconstructing radiocarbon level changes during the Late Glacial by using a laminated sequence of Gosciaz Lake. Radiocarbon 34, 826-832.

Goslar, T., Kuc, T., Ralska-Jasiewiczowa, M., Rozanski, K., Arnold, M., Bard, E., van Geel, B., Pazdur, M.F., Szerozynska, K., Wicik, B., Wieckowski, K., Walanus, A., 1993. High-resolution lacustrine record of the Late Glacial/Holocene Transition in Central Europe. Quaternary Science Reviews 12, 287-294.

Grönvold, K., Skarsson, N., Johnsen, S.J., Clausen, H.B., Hammer, C.U., Bond, G., Bard, E., 1995. Ash layers from Iceland in the Greenland GRIP ice core correlated with oceanic and land sediments. Earth and Planetary Science Letters 135, 149-155.

Gulliksen, S., Birks, H.H., Possnert, G., Mangerud, J., 1998. The calendar age of the Younger Dryas-Holocene boundary at Kråkenes, western Norway. The Holocene 8, 249-259.

Haflidason, H., Eríksson, J., Van Kreveld, S., 2000. The tephrochronology of Iceland and the North Atlantic region during the Middle and Late Quaternary: a review. Journal of Quaternary Science 15, 3-22.

Hajdas, I., Ivy-Ochs, S.D., Beer, L., Bonani, G., Imboden, D., Lotter, A.F., Sturm, A.F., Suter, M., 1993. AMS radiocarbon dating and varve chronology of Lake Soppensee: 6000 to $12,000{ }^{14} \mathrm{C}$ years BP. Climate Dynamics 9, 107-116.

Hajdas, I., Ivy-Ochs, S.D., Bonani, G., 1995a. Problems in the extension of the radiocarbon calibration curve (10-13 kyr BP). Radiocarbon $37,75-79$.

Hajdas, I., Ivy-Ochs, S.D., Bonani, G., Lotter, A.F., Zolitschka, B., Schlüchter, C., 1995b. Radiocarbon age of the Laacher See Tephra, $11,230+40$ BP. Radiocarbon 37, 149-154. 
Hammer, C.U., Andersen, K.K., Clausen, H.B., Dahl-Jensen, D., Schøtt Hvidberg, C., Iversen, P., 1997. The stratigraphic dating of the GRIP ice core. Special Report, Geophysical Department, Niels Bohr Institute for Astronomy, Physics and Geophysics, University of Copenhagen, Copenhagen.

Hoek, W.Z., Bohncke, S.J.P. 2001. Oxygen-isotope wiggle-matching as a tool for synchronising ice-core and terrestrial records over Termination 1. Quaternary Science Reviews.

Hughen, K.A., Overpeck, J.T., Lehman, S.J., Kashgarian, M., Southon, J., Peterson, L.C., Alley, R., Sieman, D.M., 1998a. Deglacial changes in ocean circulation from an extended radiocarbon calibration. Nature 391, 65-68.

Hughen, K.A., Overpeck, J.T., Lehman, S.J., Kashgarian, M., Southon, J., Peterson, L.C., 1998b. A new ${ }^{14} \mathrm{C}$ calibration data set for the Last Deglaciation based on marine varves. Radiocarbon 40, 483-494.

Huntley, B., Watts, W.A., Allen, J.R.M., Zolitschka, B., 1999. Palaeoclimate, chronology and vegetation history of the Weichselian Lateglacial: comparative analysis of data from three cores at Lago Grande di Monticchio, southern Italy. Quaternary Science Reviews $18,945-960$.

Johnsen, S.J., Clausen, H.B., Dansgaard, W., Gundestrup, N.S., Hammer, C.U., Andersen, U.A., Hvidberg, C.S., Dahl-Jensen, D., Steffensen, J.-P., Shoji, H., Sveinbjörnsdóttir, A.E., White, J., Jouzel, J., Fisher, D., 1997. The $\delta^{18} \mathrm{O}$ record along the Greenland Ice Core Project deep ice core and the problem of possible Eemian climatic instability. Journal of Geophysical Research 102, 26397-26410.

Kanfoush, S.L., Hodell, D.A., Charles, C.D., Guilderson, T.P., Mortyn, P.G., Ninnemann, U., 2000. Millennial-scale instability of the Antarctic ice sheet during the Last Glaciation. Science 288, 1815-1818.

Kilian, M.R., van Geel, B., van der Plicht, J., 2000. ${ }^{14} \mathrm{C}$ AMS wiggle matching of raised bog deposits and models of peat accumulation. Quaternary Science Reviews 19, 1011-1033.

Kitagawa, H., van der Plicht, J., 1998b. Atmospheric radiocarbon calibration to $45,000 \mathrm{yr}$ B.P.: late glacial fluctuations and cosmogenic isotope production. Science 279, 1187-1190.

Kitagawa, H., van der Plicht, J., 1998a. A 40,000 year varve chronology from Lake Suigetsu, Japan: extension of the ${ }^{14} \mathrm{C}$ calibration curve. Radiocarbon 40, 505-515.

Kristiansen, I.L., Mangerud, J., Lomo, L., 1988. Late Weichselian/early Holocene pollen- and lithostratigraphy in lakes in the Ålesund area, western Norway. Review of Palaeobotany and Palynology 53, 185-231.

Kromer, B., Spurk, M., Remmele, S., Barbetti, M., Toniello, V., 1998. Segemetns of atomospheric ${ }^{14} \mathrm{C}$ change as derived from Lateglacial and Early Holocene floating free-fugseries. Radiocarbon 40, 351-358.

Leroy, S.A.G., Zolitschka, B., Negendank, J.F.W., Seret, G., 2000. Palynological analyses in the laminated sediment of Lake Holzmaar (Eifel, Germany): duration of Lateglacial and Preboreal biozones. Boreas 29, 52-71.

Litt, T., Brauer, A., Goslar, T., Merkt, J., Balaga, K., Müller, H., Ralska-Jasiewiczowa, M., Stebich, M., Nedendank, J.F.W. 2001. Correlation and synchronisation of Lateglacial continental sequences in northern central Europe based on annually-laminated lacustrine sediments. Quaternary Science Reviews.

Lowe, J.J. Abrupt climatic changes in Europe during the last Glacial-Interglacial transition: the potential for testing the synchroneity of climatic events using tephrochronology. Global and Planetary Change, in press.

Lowe, J.J., Walker, M.J.C., 2000. Radiocarbon dating the last Glacial-Interglacial transition (ca $14-9{ }^{14} \mathrm{C}$ ka BP) in terrestrial and marine records: the need for new quality assurance protocols. Radiocarbon 42, 53-68.

Mangerud, J., Andersen, S.T., Berglund, B.E., Donner, J.J., 1974. Quaternary stratigraphy of Norden, a proposal for terminology and classification. Boreas 3, 109-126.
Mangerud, J., Lie, S.E., Furnes, H., Kristiansen, I.L., Lomo, L., 1984. A Younger Dryas ash bed in western Norway and its possible correlations with tephra beds from the Norwegian Sea and North Atlantic. Quaternary Research 21, 85-104.

Meese, D.A., Gow, A.J., Alley, R.B., Zielinski, G.A., Grootes, P.M., Ram, M., Taylor, K.C., Mayewski, P.A., Bolzan, J.F., 1997. The Greenland Ice Sheet Project 2 depth-age scale: methods and results. Journal of Geophysical Research 102, 26411-26423.

Reimer, P.J., Reiner, R.W. Amarine reservoir correction database and on-line interface. Radiocarbon, in press.

Renssen, H., van Geel, B., van der Plicht, J., Magny, M., 2000. Reduced solar activity as a trigger for the start of the Younger Dryas?. Quaternary International 68-71, 373-383.

Schwander, J., Eicher, U., Ammann, B., 2000. Oxygen isotopes of lake marl at Gerzensee and Leysin (Switzerland), covering the Younger Dryas and two minor oscillations, and their correlation to the GRIP ice core. Palaeogeography, Palaeoclimatology, Palaeoecology $159,203-214$.

Sikes, E.L., Samson, C.R., Guilderson, T.P., Howard, W.R., 2000. Old radiocarbon ages in the southwest Pacific Ocean during the last glacial period and deglaciation. Nature 405, 555-558.

Speranza, A., van der Plicht, J., van Geel, B., 2000. Improving the time control of the Subboreal/Subatlantic transition is a Czech peat sequence by the ${ }^{14} \mathrm{C}$ Wiggle-matching. Quternary Science Reviews 19, 1589-1604.

Spurk, M., Friedrich, M., Hofman, J., Remmele, S., Frenzel, B., Leuschner, H.H., Kromer, B., 1998. Revision and extension of the Hohenheim oak and pine chronologies: new evidence about the timing of the Younger Dryas/Preboreal transition. Radiocarbon 40, $1107-1116$.

Stephens, B.B., Keeling, R.F., 2000. The influence of Antarctic sea ice on Glacial-Interglacial $\mathrm{CO}_{2}$ variations. Nature 404, 171-174.

Stuiver, M., Grootes, P.M., 2000. GISP2 oxygen isotope ratios. Quaternary Research 53, 277-284.

Stuiver, M., Reimer, P.J., Bard, E., Beck, W., Burr, G.S., Hughen, K.A., Kromer, B., McCormac, G., van der Plicht, J., Spurk, M., 1998. INTCAL98 radiocarbon age calibration 24,000-0 cal BP. Radiocarbon 40, 1041-1083.

Stuiver, M., Van der Plicht, J. (Eds.), 1998. INTCAL98: Calibration University of Arizona, Tucson. Issue. Radiocarbon, Vol. 40/3.

Turney, C.S.M., Coope, G.R., Harkness, D.D., Lowe, J.J., Walker, M.J.C., 2000. Implications for the dating of Wisconsinan (Weichselian) Lateglacial events of systematic radiocarbon age differences between terrestrial plant macrofossils from a site in SW Ireland. Quaternary Research 53, 114-121.

Turney, C.S.M., Harkness, D.D., Lowe, J.J., 1997. The use of micro-tephra horizons to correlate Lateglacial lake sediment successions in Scotland. Journal of Quaternary Science 12, 525-531.

Turney, C.S.M., Lowe, J.J., Wastegård, S., Cooper, R., Roberts, S.J. The development of a tephrochronological framework for the last glacial-Holocene transition in NW Europe. Le Quaternaire, in press.

Van den Bogaard, P., Schminke, H., 1985. Laacher See Tephra: a widespread isochronous late Quaternary tephra layer in central and northern Europe. Geological Society of America Bulletin 96, 1554-1571.

Van Geel, B., Buurman, J., Waterbolk, H.T., 1996. Archaeological and palaeoecological indications of an abrupt climate change in The Netherlands, and evidence for climatic teleconnections around 2650 BP. Journal of Quaternary Science 11, 451-460.

Voelker, A.H.L., Sarnthein, M., Grootes, P.M., Erlenkauser, H., Laj, C., Mazaud, A., Nadeau, M.-J., Schleicher, M., 1998. Correlation of marine ${ }^{14} \mathrm{C}$ ages from the Nordic seas with the GISP2 isotope record: implications for radiocarbon calibration beyond $25 \mathrm{ka} \mathrm{BP}$. Radiocarbon 40, 517-534.

Von Grafenstein, U., Erlenkauser, H., Brauer, A., Jouzel, J., Johnsen, S.J., 1999. A mid-European decadal isotope-climate record from 15,500 to 5,000 years BP. Science $284,1654-1657$. 
Walker, M.J.C. Rapid climatic changes during the Last GlacialInterglacial Transition: implications for stratigraphic subdivision, correlations and dating. Global and Planetary Change, in press.

Walker, M.J.C., Björck, S., Lowe, J.J., Cwynar, L.C., Johnsen, S.J., Knudsen, K.-L., Wohlfarth, B., INTIMATE Group, 1999. Isotopic 'events' in the GRIP ice core: a stratotype for the Late Pleistocene. Quaternary Science Reviews 18, 1143-1150.

Walker, M.J.C., Bryant, C., Coope, G.R., Harkness, D.D., Lowe, J.J., Scott, E.M. Towards a radiocarbon chronology for the Lateglacial in Britain. Radiocarbon, in press.

Wastegård, S., Björck, S., Possnert, G., Wohlfarth, B., 1998. Evidence for the occurrence of Vedde Ash in Sweden: radiocarbon and calendar age estimates. Journal of Quaternary Science 13, 271-274.

Wastegård, S., Turney, C.S.M., Lowe, J.J., Roberts, S.J., 2000. New discoveries of the Vedde Ash in southern Sweden and Scotland. Boreas 29, 72-78.

Wohlfarth, B., 1996. The chronology of the Last Termination: a review of radiocarbon-dated, high-resolution terrestrial stratigraphies. Quaternary Science Reviews 15, 267-284.

Zolitschka, B., 1999. High-resolution records from European Lakes. Special Issue of Quaternary Science Reviews 18, 885-992.

Zolitschka, B., Brauer, A., Negendank, J.F.W., Stockhausen, H., Lang, A., 2000. Annually dated late Weichselian continental paleoclimate record from the Eifel, Germany. Geology 28, 783-786. 